Rev. High Pressure Sci. Technol., Vol. 7 (1998) 1532 1534

\title{
New High-pressure Hot Stage for Optical Microscopy: in situ Observation of Texture of Liquid Crystals under Hydrostatic Pressure
}

\author{
Y. Maeda and M. Koizumi* \\ National Institute of Materials and Chemical Research, Tsukuba, Ibaraki 305, Japan \\ *Hikari High-Pressure Machinery Co., Ltd., Hiroshima 733, Japan
}

\begin{abstract}
High-pressure hot-stage system for optical microscopy was developed for the in situ observation of texture of liquid crystals and crystal growth of polymers under hydrostatic pressures up to $300 \mathrm{MPa}$. The high-pressure optical cell has two sapphire windows of $5 \mathrm{~mm}$ in diameter at the center of the cell. The spherullites of the pressure-induced crystal polymorph of the dimesogenic liquid crystal compound was observed successfully on cooling at 100 and $150 \mathrm{MPa}$. [ High-pressure hot stage, optical microscopy, texture, liquid crystal, crystal polymorph ]
\end{abstract}

\section{Introduction}

Microscopic observation is important for the characterization of texture of liquid crystals that show specific textures characteristic of the various smectic, nematic, and cholesteric mesophases. Several polymorphisms often appear in a small temperature region at atmospheric pressure. If such liquid crystals can be observed under hydrostatic pressure, there might be a significant possibility of research for both crystalline and mesophasic polymorphisms of liquid crystals at high pressure. In fact, polymorphisms in liquid crystals appear at relatively low pressures around $100 \sim 200 \mathrm{MPa}$. There are a few reports on morphological texture of liquid crystals under pressure that were performed with a compact diamond-anvil cell(DAC): the sample volume is very small in the DAC and pressure is measured either directly by detecting the change in wavelength of ruby fluorescence or indirectly by using some reference materials in which the $\mathrm{T}$ vs $\mathrm{P}$ relation is already known. However, liquid crystals and polymer films often have to be measured with a macroscopic size, at least, of several millimeters in length and width. Furthermore the texture of liquid crystals having several polymorphisms are usually observed in the mode of temperature scanning. In this study we report a high-pressure optical hot stage system for optical microscopy that can be controlled precisely at any temperature and pressure in either an isobaric or an isothermal way, and the in-situ observation of the spherulitic growth of the crystal polymorph of the dimesogenic liquid crystal compound under hydrostatic pressures up to $300 \mathrm{MPa}$.

2. Experimental

The high-pressure optical cell is used on the stage of a commercial optical microscope, which is equipped with an objective lens having a long working distance(Leitz UM20 32, (Olympus CDPlan 20). Figure 1 shows the photograph of the high-pressure hot-stage cell set on the stage of a optical microscope. The hot-stage cell is thermally insulated by ceramic covers and water circulation in a spiral tube beneath the cell. The high-pressure cell was machined from maraging steel(YAG300, Hitachi Metals, Inc.). It contains two sapphire windows with diameters of $5 \mathrm{~mm}$, each facing each other at the top and bottom surfaces. The sapphire optical windows are lined up to transmit the light from the polarizing optical microscope. Pressure is generated by a manual-operatring oil

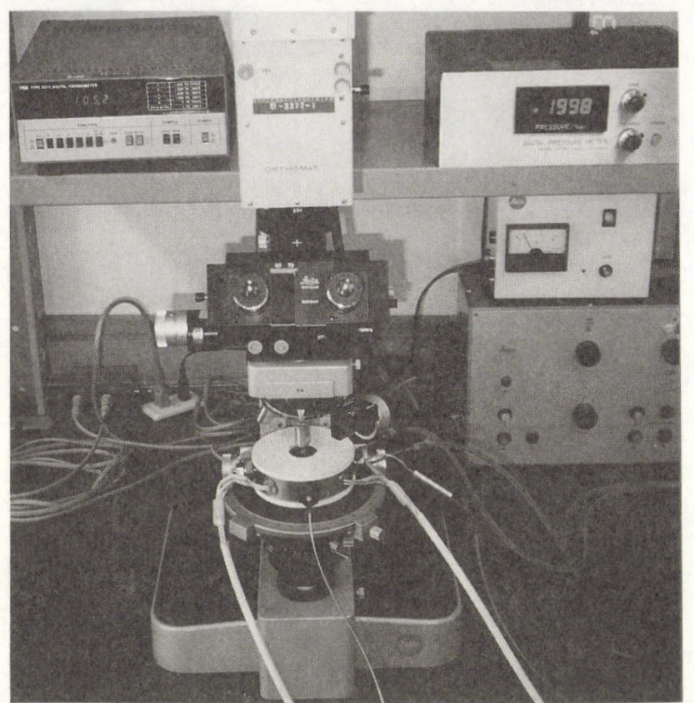

rig.1. Photograph of the high-pressure hot-stage cell set on the stage of a optical microscope.

pump using low-viscosity silicone oil(10 centistokes, TSF451, Toshiba Silicone Co.) as the pressure medium. The pressure pump is connected to a manganin coil gauge for pressure measurement, an oil reservoir, and a high-pressure optical cell in series. The oil reservoir is connected to the optical hot-stage cell by a flexible high-pressure capillary tube(0.015 and 1/14 in. i.d. and o.d., respectively, Harwood Engineering Inc.) of about $1 \mathrm{~m}$ in length. Pressure is measured with an accuracy of \pm 1 $\mathrm{MPa}$ by the manganin gauge, which was calibrated by an accurate broudon gauge(Heise CM, Dresser Industries, Inc.) as a secondary pressure standard. The high-pressure cell is heated either automatically or manually by embedded cartridge-type electric heaters(Firerod Heater, Watlow Electric Co.). The temperature is monitored by a sheathed C-A thermocouple inserted into the pressure cell, and the top of the thermocouple is inserted within the steel holder including the slide glasses. The optical hot-stage cell is used in a temperature region ween room temperature and $250 \sim 300^{\circ} \mathrm{C}$ under hydrostatic 
pressures up to $300 \mathrm{MPa}$. Figs.2(a) and 2(b) show the diagrams viewed from the top and the side of the high-pressure optical hot stage cell, respectively. The sapphire windows are set with the copper O-rings and copper spacers between the sapphire block and the cell, and they are fixed by screwing the steel nut tightly. Sample is prepared as a film on a minituare slide glass $5 \mathrm{~mm}$ wide by $7 \mathrm{~mm}$ long, and then covering it with a thin glass cover. The slide galsses are held horizontally by setting it into a steel holder and then inserted into the high-pressure optical cell.

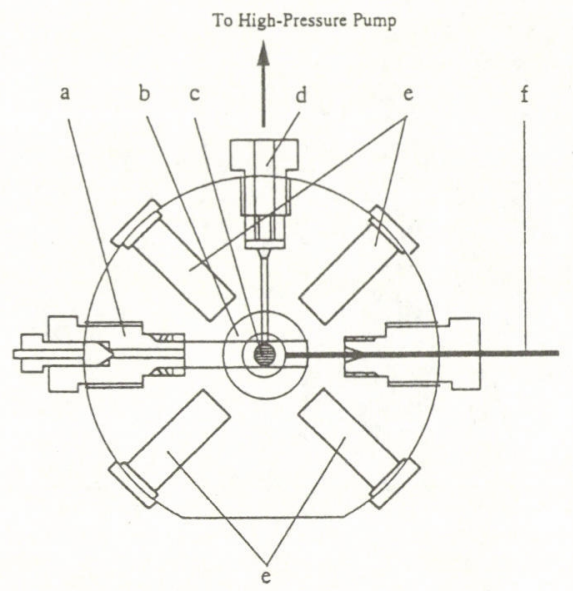

(a)
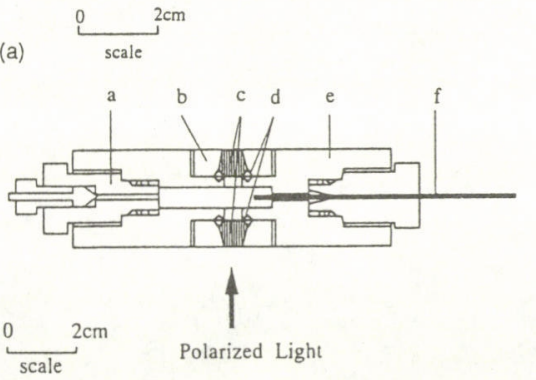

(b)

Fig.2. (a) Diagram of the high-pressure optical cell (viewed from the top): a: high-pressure plug for sample insertion; b: steel plug for sapphire window; c: sapphire window; d: highpressure plug connected to the capillary tube; e: cartridge-type electric heaters: and f: C-A sheathed thermocouple.

(b) Diagram of the high-pressure optical cell (viewed from the side); a: high-pressure plug for sample insertion; b: steel plug for sapphire window; c: sapphire windows; d: copper O-rings; e: body of the hot-stage cell: and f: C-A sheathed thermocouple.
3. In situ observation of texture of a crystal polymorph by high-pressure hot-stage cell

Dimesogenic liquid crystal compound containing cholestery] and smectogenic units, $\mathrm{N}$-[4-(6-cholestryloxycarbonyl)pentyloxy )-benzylidene]-4-n-butylabiline, called as KI5, exhibits several mesomorphisms including two incommensurate smectic $\mathrm{A}($ SAinc) phases as well as cholesteric and helical smectic $\mathrm{C}$ phases(TGB and $\mathrm{Sc}^{*}$ phases) between the normal crystal(CI) and isotropic liquid(I). The transition scheme of KI5 compound is: $\mathrm{C}_{\mathrm{I}}-\mathrm{S}_{1}-\mathrm{S}_{\text {Ainc }}-\mathrm{Sc}^{*}-\mathrm{S}_{\text {Ainc }}-\mathrm{Sc}^{*}-\mathrm{TGB}-\mathrm{N}^{*}-\mathrm{I}$. Fig. 3 illustrates the typical DSC heating curve with symbols in texture of the successively appearing mesomorphic phases.

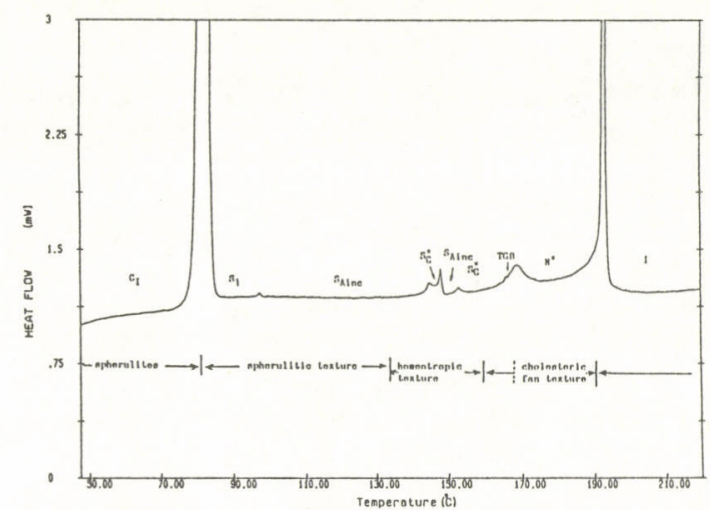

Fig.3 DSC heating curve of the KI5 compound coded with characteristic texture.

A X-ray structural study on the phase transition of the $\mathrm{KI} 5$ compound under pressure shows that a crystal polymorph(CII) is formed concurrently with the Cr crystal at pressures above about $20 \mathrm{MPa}$, and that the formation of the CII crystal is predominant with increasing pressure above about $100 \mathrm{MPa}$. An in-situ observation of the formation of the CII crystal from the I phase under pressure was performed by a polarized optical microscope equipped with the high-pressure optical hot-stage system. Fig. 4 shows the polarized optical micrographs of the $\mathrm{KI} 5$ compound on cooling at $50 \mathrm{MPa}$. The crystal growth of the CII spherullites with diameters of about $50 \mu \mathrm{m}$, different from the spherullites of the CI crystal, is observed successfully by the polarizing optical microscopic observation under pressure.

Acknowledgement. We would like to thank Prof. J.-I. Jin of Korea University for supplying the KI5 dimesogenic liquid crystal Compound.

\section{References}

[1] R. Shashidhar, A. N. Kalkura, S. Chandrasekhar, Mol. Cryst. Liq. Cryst. Lett., 64, 101(1980).

[2] Y. Maeda, M. Koizumi, Rev. Sci, Instrum., 67, 2030 (1996).

[3] Y. Maeda, Y.-K. Yun, J.-I. Jin, Mol. Cryst. Liq. Cryst., 80, 85(1996). 

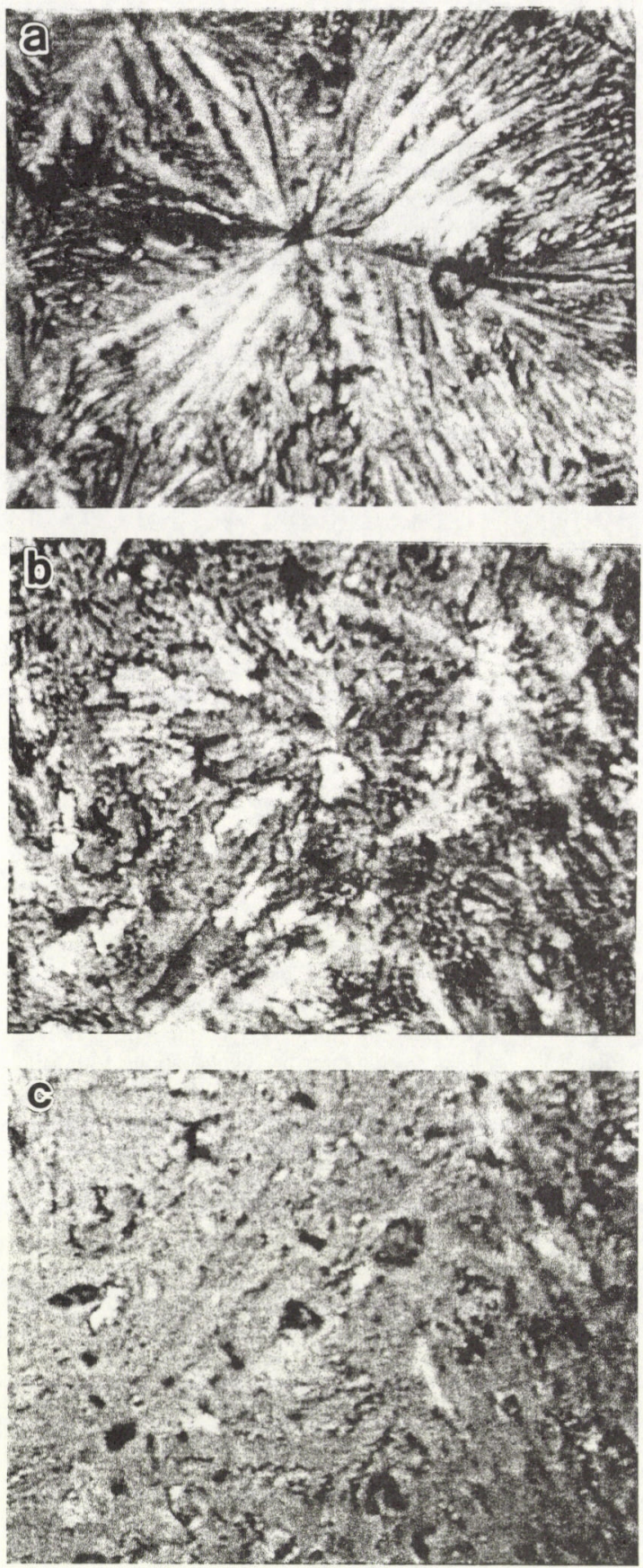
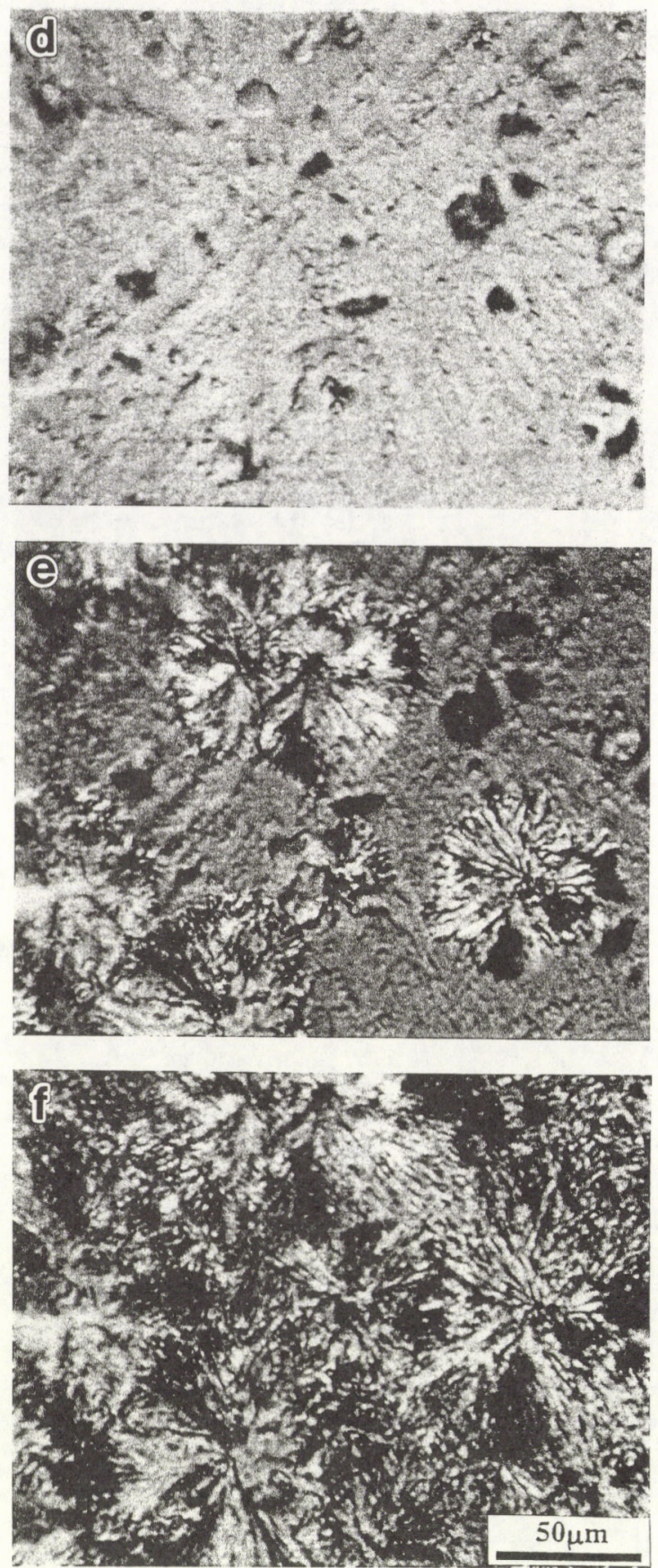

Fig.4 Polarized optical micrographs of the $\mathrm{KI} 5$ compound at $50 \mathrm{MPa}$ : a, $\mathrm{C}_{1}$ spherullites at $27^{\circ} \mathrm{C} ; \mathbf{b}, \mathrm{C}_{\mathrm{II}}$ crystal at $96^{\circ} \mathrm{C}$ on heating; c. texture change from $\mathrm{C}_{11}$ crystal to homeotropic state at $110^{\circ} \mathrm{C}$; d, homeotropic state at $170^{\circ} \mathrm{C}$; e, growth of the $\mathrm{C}_{11}$ spherullites at $78^{\circ} \mathrm{C}$ on cooling; and $\mathbf{f}, \mathrm{C}_{\mathrm{II}}$ spherullites at $35^{\circ} \mathrm{C}$ on cooling. 